\title{
PENDEKATAN TEORI HUKUM PROGRESIF DALAM MENJAWAB PERMASALAHAN KESEJANGAN HUKUM (LEGAL GAPS) DI INDONESIA
}

\author{
Satria Sukananda \\ Universitas Islam Indonesia, Email : artisukananda@gmail.com
}

\begin{abstract}
ABSTRAK
Potensi-potensi penyimpangan dalam berhukum melahirkan apa yang disebut jurang hukum (legal gaps). Jurang atau lacuna yang terjadi sesungguhnya berproses melalui pola-pola sederhana. Hal ini dapat terjadi karena masyarakat senantiasa berproses, sedangkan hukum positif cenderung mengkristal sebagai produk, ketika persentuhan ini terjadi, ada kemungkinan hukum positif tadi tidak secara tepat mampu menjawab kebutuhan dalam peristiwa konkret. Hasil kajian ini menunjukkan bahwa pendekatan teori hukum progresif dapat menjawab permasalahan tersebut. Progresifitas dalam berhukum menuntut ada keberanian untuk melakukan terobosan guna mencairkan kebekuan tadi, sekaligus membangun jembatan diatas jurang hukum (legal gaps) tadi melalui penemuan-penemuan hukum agar dapat menseleraskan kepastian hukum, keadilan dan kemanfaatan bagi masyarakat Indonesia.
\end{abstract}

Kata-kata kunci : Hukum Positif, Jurang hukum (legal gaps), Teori Hukum Progresif, Progresifitas

\begin{abstract}
Issue of Potential deviation in the law raises a gap in the law. Gap or lacuna proceeds through of simple patterns. This event occurs because society is always processed, whereas positive law tends to crystallize into as products, when this contact occurs, there is a possibility that the positive law is not able to answer the problem in society. The Result of the research shows Progresive Law Theory Approach can answer the problem. Progressiveness in the law requires a courage to make a breakthrough to overcome legal gaps, through the discovery of the law in order to created justice, benefit and legal certainty in society.
\end{abstract}

Keywords: Positive Law, Legal Gaps, Progressive Law Theory, Progressiveness

\section{PENDAHULUAN}

Produk legislasi yang diposisikan sebagai salah satu objek paling resprensentif dari hukum, adalah sebuah karya normative. Pada galibnya, semua yang normative membuka diri untuk terjadinya penyimpangan. Hukum-hukum normative berkaitan erat dengan hukum kemanusiaa, 
mengingat hanya manusia yang layak disebut sebagai makhluk normatif (Sidharta, 2009: 47-48). Potensi-potensi penyimpangan dalam berhukum melahirkan apa yang disebut jurang hukum (legal gap). Jurang atau lacuna yang terjadi sesungguhnya berproses melalu pola-pola sederhana. Proses tersebut diawali dari ketersediaan hukum positif yang berada dalam penantian untuk diaktiasi melalui persentuhan dengan peristiwa konkret. Ketika persentuhan ini terjadi, ada kemungkinan hukum positif tadi tidak secara tepat mampu menjawab kebutuhan dalam peristiwa konkret.

Hal di atas terjadi terutama karena hukum positif sebagai suatu produk hukum, selalu dipersepsikan memotret masyarakat dalam konteks penggalan waktu tertentu (sinkronis). Seperti sudah diutarakan sebelumnya, hasil potret ini memperlihatkan system hukum sebagai karya momentaris (momentary legal system). Disisi lain, disadari atau tidak disadari, masyarakat mengalami pergolakan tanpa mengenal titik perhentian. Masyarakat senantiasa berproses, sedangkan hukum positif cenderung mengkristal sebagai produk.

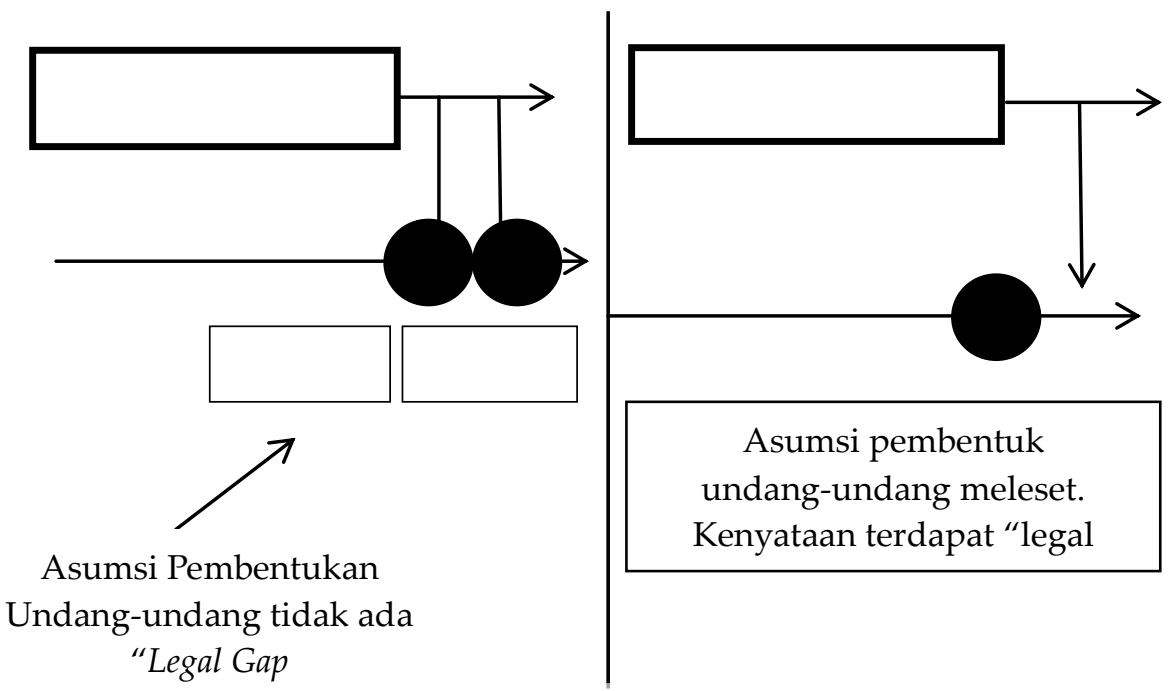

Robert B. Seidman menyatakan bahwa "The law of the non transferability of law" Pada prinsipnya teori ini menyatakan bahwa "tidak semua aturan yang berlaku pada suatu masyarakat tertentu dapat ditransfer dan berlaku dengan baik pada masyarakat lain karena adanya perbedaan sistem nilai yang dianut oleh masyarakat bersangkutan 
(Hamzah, 2017). Melihat dari kondisi Indonesia yang beraneka ragam budaya dan adat istiadat serta kaya dengan hukum kebiasaan atau hukum adat masing-masing daerah, pandangan Robert B. Seidman sangat tepat digunakan, karena system hukum positif Indonesia memang tidak dapat dipaksakan dalam beberapa daerah di Indonesia.

Teori tersebut diatas dikuatkan oleh pandangan Eugen Ehrlich dalam bukunya Fundamental Principles of The Law Sociology of Law, 1975 yang menyatakan Law is always society as well as society is always in the law, bahwa hukum Negara yang dikenali juga sebagai hukum perundang-undangan nasional yang positif itu tidak berawal dari rakyat yang hidup dalam masyarakat, Menyadari bahwa hukum nasional yang diberlakukan lewat proses transplantasi ke masyarakat tertentu yang berbeda secara sosial-kultural itu tak selamanya dengan cepat bisa diterima penduduk setempat dan memperoleh kebermaknaannya. Akibatnya terjadi apa yang disebut legal gaps. Terjadi jurang perbedaan antara apa yang dipreskripsikan oleh undang-undang dan apa yang ada di alam kesadaran warga masyarakat tentang mana yang hukum dan mana yang bukan. Penerapan hukum Barat ke wilayah-wilayah jajahan pada waktu yang lalu telah menyebabkan terjadinya legal gaps yang manifes dalam kenyataan bahwa law is not society, dan pada ujung-ujungnya akan menimbulkan kekacauan dalam tertib hukum kolonial (Marzuki, 2017).

Dua tokoh Pengiat Sosiologi hukum yaitu Prof. Dr. Satjipto Raharjo, S.H., dan Prof Soetandyo Wignjosoebroto, MPA juga mengemukakan hal yang sama, bahwa akan terjadi legal gaps atau kegagalan transplantasi hukum ketika hukum positif dipaksakan kedalam hukum kebiasaan masyarakat sehingga terjadi legal gaps pada system hukum Indonesia, akan tetapi setelah kepergian 2 begawan itu yaitu Prof. Dr. Satjipto Raharjo, S.H, diikuti dengan sahabatnya, Prof. Soetandyo Wignojosoebroto, MPA, kita dihadapkan sebuah kefrustasian berat. Sudah tidak ada lagi tempat mengadu. Sudah tidak ada lagi petuah-petuah jernih untuk menyiram kegersangan dunia hukum yang tandus ini. Keluh-kesah penat yang menyerang dunia hukum yang diwarnai korupsi, skandal kekuasaan, kemarahan, amarah, dst. Telah kehilangan kesejukannya kata-kata para Begawan itu telah tak lagi kita dapatkan dalam ruas-ruas ruang publik. Tulisan-tulisan para Begawan pun raib laksana ditelan bumi. Tapi semua 
orang selalu menepuk pundak pada pemuda yang masih memegang idelasme, mereka tidak pergi tanpa sisa, bahkan jiwa mereka menyatu dengan kalbu kita, modal yang berharga untuk mengarungi samudera kehidupan hukum Indonesia yang penuh dengan badai ini (Suteki, 2013: v).

Salah satu peristiwa adanya kesejangan antara hukum positif dan hukum adat masyarakat adalah Pada 19 November 2009, nenek Minah yang berumur 55 Tahun dihukum oleh Pengadilan Negeri (PN) Purwokerto selama 1 bulan 15 hari penjara dengan masa percobaan 3 bulan. Dia dinyatakan bersalah karena memetik 3 buah kakao di perkebunan milik PT Rumpun Sari Antan (RSA), Ajibarang, Banyumas. Selama persidangan dengan agenda putusan berlangsung penuh keharuan. Bahkan ketua majelis hakim yang mempimpin persidangan pada saat itu, Muslih Bambang Luqmono SH, terlihat menangis saat membacakan vonis (Saputra, 2017). Hal ini adalah bukti terjadinya kesejangan antara hukum positif dan hukum adat karena pada hukum adat masyarakat setempat mengambil ranting dan buah-buahan yang sudah jatuh ketanah merupakan hal yang wajar dalam perspektif hukum masyakarat banyuwangi tersebut, sebaliknya menurut hukum positif hal itu jelas melanggar ketentuan pada pasal 362 Kitab Undang-Undang Hukum Pidana (KUHP) yang mengatur tentang delik pencurian (Marzuki, 2017).

Peristiwa lainya adalah Mantri desa, Misran, dipidana penjara 3 (tiga) bulan oleh PN Tenggarong pada tahun 2009. Dia dihukum karena menolong orang tetapi dianggap salah karena bukan dokter. Putusan ini lalu dikuatkan oleh PT Samarinda, beberapa waktu setelah itu. Akibat putusan pengadilan ini, 8 mantri memohon keadilan ke Mahkamah Konstitusi (MK) karena merasa dikriminalisasikan oleh UU Kesehatan. Lantas, MK mengabulkan permohonan Misran pada 27 Juni 2011. Akibat dikabulkannya permohonan ini, maka mantri desa di seluruh Indonesia boleh melayani masyarakat layaknya dokter atau apoteker dalam kondisi darurat. MK menilai pasal 108 ayat (1) UU No. 36 Tahun 2009 bertentangan dengan UUD 1945. Pasal yang tidak mempunyai kekuatan hukum yaitu sepanjang frase" harus dilakukan oleh tenaga kesehatan yang mempunyai keahlian dan kewenangan sesuai peraturan perundangan (Marzuki, 2017). Melihat dari kenyataannya keberadaan matri desa masih juga eksis di beberapa daerah di Indonesia, dan masyarakat penduduk desa masih 
sangat mempercayai mantri dari pada dokter.

Kasus lainya adalah PN Jakpus pada 3 Mei 2010 memvonis bebas Chairul Saleh seorang pemulung yang dituduh memiliki ganja seberat 1,6 gram. Pria 38 tahun ini dipaksa mengakui memiliki ganja oleh sejumlah oknum polisi ini. Orang nomor 1 di tubuh Polri waktu itu, Jenderal Polisi Bambang Hendarso Danuri pun turun tangan untuk menindaklanjuti kasus dugaan rekayasa ini. Dia langsung menelpon Kapolda Metro Jaya Irjen Wahyono untuk meminta kepastian adanya rekayasa tersebut. Dalam sidang disiplin Propam Polres Jakpus menjatuhkan hukuman kepada 4 polisi yang terlibat dalam rekayasa kasus kepemilikan ganja terhadap pemulung Chairul Saleh ini. Kanit Narkoba Polsek Kemayoran Aiptu Suyanto didemosi sedangkan penyidik Brigadir Rusli ditunda kenaikan pangkatnya selama 1 tahun. Kemudian Aiptu Ahmad Riyanto ditunda kenaikan pangkat selama satu tahun, serta dimutasi secara demosi. Dan untuk Brigadir Dicky ditempatkan ke tempat khusus selama 7 hari (Marzuki, 2017). Hal ini juga membuktikan kelebihan kewenangan yang diatur didalam Undang-Undang Nomor 8 Tahun 1981 Tentang Hukum Acara Pidana (KUHAP) kepada Penegak Hukum dalam hal ini Kepolisian dalam menimbulkan Penyalahgunaan Kekuasaan (Abuse Of Power) dan tidak lagi menjalankan Due Process of law yang baik dan benar, hal ini juga pernah dikemukakan oleh Lord Acton (John Emerich Edward Acton (1834 - 1902) "Power Tends to Corrupt, but Absolute Power Corrupt Absolutely".

Berkaitan kasus dengan pandangan tersebut diatas, teori hukum progresif adalah pandangan yang tepat dalam mengkaji hukum, hukum progresif tidak hanya memandang Hukum dari segi positivisme melainkan juga memandang hukum sebagai kenyataan sosial, Memandang hukum bukan semata-mata sebagai Undang-Undang Produk Kekuasaan, tetapi produk sosial, memandang hukum tidak berada di ruang hampa, tetapi dalam realitas kehidupan nyata, jika hukum normatif cenderung pada Quid Juris (Normatif, Sollen), tetapi teori hukum progresif Cenderung Pada Quid Facti/Alamiah, Empiris/Sein (Marzuki, 2017). Pentinghalnya mengkaji bagaimana Teori hukum Progresif untuk meningkatkan daya mampu hukum Positif menyelesaikan persoalan-persoalan nyata di Indonesia, tulisannya ini juga akan mengkaji bagaimana menjelaskan metode dan konsepsi penegakan hukum dalam perspektif Teori Hukum 
Progresif yang mampu mengawinkan kepentingan kepastian hukum, keadilan dan kemanfaatan.

\section{METODE PENELITIAN}

Penelitian ini merupakan penelitian hukum normatif dengan menggunakan studi kepustakaan yaitu penelitian hukum yang meletakkan hukum sebagai sebuah bangunan sistem norma (Fajar\&Achmad, 2010: 34). Adapun pencarian bahan di dasarkan pada bahan hukum yang telah ada baik dalam bentuk peraturan perundangan-undangan maupun karya tulis seperti buku-buku ataupun artikel lain yang terdapat dalam situs internet yang relevan dengan objek penelitian ini. Penelitian hukum normatif ini digunakan dalam memahami pendekatan teori hukum progresif dalam menjawab permasalahan kesejangan hukum (legal gaps) di Indonesia.

Pendekatan penelitian ini adalah pendekatan statute approach dan case approach. Statue approach adalah pendekatan melalui undang-undang dimana penelitian dilakukan dengan cara menelaah undang-undang dan regulasi yang bersangkut paut dengan isu hokum (Marzuki, 2005: 93). Selain itu, penelitian ini juga menggunakan pendekatan kasus (case approach) melalui studi terkait kasus-kasus hukum yang terkait dengan permasalahan penelitian (Wignjosoebroto, 2013: 67-71). Bahan hukum dan bahan non hukum yang diperoleh dalam penelitian ini akan dianalisis secara preskriptif dengan metode deduktif. Maksudnya yaitu data-data umum, asas-asas hukum, doktrin, dan peraturan perundang-undangan dirangkai secara sistematis sebagai susunan fakta-fakta hukum untuk mengkaji pendekatan teori hukum progresif dalam menjawab permasalahan kesejangan hukum (legal gaps) di Indonesia.

\section{PEMBAHASAN}

\section{Teori Hukum Progresif dalam Menjawab Permasalahan Hukum di Indonesia}

Kehadiran gagasan Hukum Progresif, justru mengunggulkan aliran realism hukum dan penggunaan optic sosiologis hukum dalam menyelesaikan persoalan hukum di indonesia, sehingga suatu saat cara berhukum progresif ini secara automatis akan melahirkan penegakan hukum progresif. Sebelum membahas konsep teori hukum progresif 
berikut ini akan dipaparkan metode sosiologi hukum sebagai induk teori hukum progresif yang melihat hukum tidak dari sisi positivism melainkan dari sisi sosiologis. metode kerja sosiologi hukum dapat dipertukarkan dengan metode ilmiah, oleh karena memenuhi standar-kerja metode keilmuan pada umumnya, yaitu (1) membuat deskripsi mengenai objek, (2) membuat penjelasan (explanation), (3) mengungkapkan (reveling), dan (4) membuat prediksi.

Sosiologi hukum berbagi sama dengan ilmu pengetahuan dalam mencari kebenaran berdasarkan kenyataan. Hal ini sangat berbeda dengan ilmu hukum normative-positivis yang bertolak dari hukum perundang-undangan. Karena pencarian pengungkapan dan penjelasan mengenai hal yang sebenarnya itu maka sosiologi hukum berseberangan dengan ilmu hukum normative tersebut yang melakukan pemihakan dan penilaian terhadap hukum. Dilihat dari segi sudut kriteria pekerjaan ilmu pengetahuan modern diatas, maka ilmu hukum yang diajarkan difakultas-fakultas hukum baru dapat disebut sebagai Pratical Science.

Usaha untuk mencari kebenaran-kenyataan tersebut menjadikan pengamatan (observation) sangat sentral dan yang menjadikan sosiologi hukum sebagai ilmu pengetahuan empiric. Sewaktu mengamati pengadilan, Marc Galanter mengatakan bahwa berbeda dengan cara tradisional (maksudnya: normative), maka ia mengamati lembaga tersebut from the other end of the telescope" (Raharjo, 2010). Maksud galanter dengan ungkapan tersebut adalah, bahwa hukum tidak dilihat dari perundang-undangan, melainkan dari lapangan. Dikatakan Galanter, "Most Analyses of the legal system start at the rules end and work down through institutional facilities to see what effect the rules have on the parties. I would like to reverse that procedure and look through the other end of the telescope....(Raharjo, 2010). Undang-Undang tidak memberikan gambaran epada kita mengenai kompleksitas bekerjaannya system pengadilan pada waktu ia benar-benar dijalankan oleh para pelaku yang tidak lain adalah anggota masyarakat. Masyarakat ini sarat dengan perbedaan-perbedaan, baik secara ekonomi maupun sosial. Perbedaan-perbedaan, baik secara ekonomi maupun sosial. Perbedaan-perbedaan tersebut tak terhindar pada waktu para pelaku dalam proses peradilan bertemu, seperti dikatakan oleh galanter berikut 
ini, "Because difference in their size, difference in the state of the law, and difference in their resource, some of the actors in the society have mant occsions to utilize the courts (in the broad sense) to make (or defend) claims; others do so only rarely..." (Raharjo, 2010: 60). Dalam hubungan dengan potret sosiologis dari hukum ini, Max Weber mengatakan, "..In the Context, legal order' thus assumes a totally different meaning. It refers not to a set of norms of logically demonstrable correctness, but rather to a complex of act determinan (bestimmungsgruende) of actual human conduct..."(Raharjo, 2010: 60).

Sosiologi hukum termasuk kedalam kategori ilmu non grafik yang bertumpu pada deskripsi dan penjelasan. Eksplorasi kebenaran dilakukan oleh penelitian-penelitian sosiologi hukum yang pada akhirnya menemukan "kebenaran baru" atau mengungkapkan hal-hal yang sebelum itu tidak dipikirkan orang. Penelitian Stewart Macaulay mengenai kontrak dan Marc Galanter mengenai pengadilan dan advokat, juga Donald Black mengenai polisi, merupakan beberapa contoh dari karya sosiologi hukum. Penelitian Stewart Macaulay pada akhirnya berhasil mengungkapkan kenyataan bahwa di kalangan bisnis, perbuatan kontrak tidak selalu diikuti dengan pelaksanaannya. Hubungan antara mereka sekalipun ternyata dijalankan secara "Non-Contractual". Penelitian Macaulay Pada Tahun 1963 menimbulkan efek akademis yang sangat mengejutkan yang hemanya masih terdengan dua puluh tahun kemudian (Raharjo, 2010: 60).

Demikian pula dengan penelitian Marc Galanter yang menggambarkan dan menjelaskan bagaimana dalam kenyataannya pengadilan tampil sebagai masyarakat tersendiri dari pihak-pihak dengan kekuatan dan kedudukan berbeda-beda serta mengejar pemuasan kepentingannya sendiri melalui pengadilan. Sesungguhnya para professional hukum yang sangat memuliakan pekerjaannya (dedicated), seperti hakim, faham benar mengenal kompleksitas tersebut. Tetapi karena tuntutan peran professional mereka yang praktis itu, maka hal tersebut tidak dilihat atau dikesampingkan. Kendati demikian, kita jumpai juga professional hukum yang mampu menangkap kompleksitas sosiologi tersebut. O.W. Holmes, seorang hakim agung Amerika yang sangat terkenal mengatakan dalam Holmesian Dictum yang terkenal, "The life of the law has not been logic, it has been experience". Bagi para 
professional hukum, memang sulit untuk menerima adanya suatu tipe tatanan lain diluar hukum perundang-undangan. Tuntutan profesi yang praktis sengaja mengabaikan realitas, seperti dikatakan oleh weber. "...For the lawyer an order is either valid or not; but so such alternative exist for the sociologist. Fluid Transitions exist between validity and nonvalidity, and mutually contradictiory orders can be valid alongside each other. Each one is valid simply in proportion to the probality that conduct will actually be oriented toward it" (Raharjo, 2010).

Metode Sosiologi Hukum dengan teori hukum progresif yang ingin menangkap kenyataan hukum yang penuh itu dimulai dengan mengajukan pertanyaan-pertanyaan, yang dalam ilmu hukum normative biasa diakui dan diterima begitu saja. Pertanyaan- pertanyaan tersebut misalnya:

a. Apakah hukum itu benar-benar melakukan apa yang dikatakanya?

b. Benarkah hukum itu mengatur masyarakat dan rakyat?

c. Apakah hukum itu benar-benar menimbulkan efek sebagaimana dikehendakinya?

d. Tidakkah justru menimbulkan efek yang berbeda, atau bahkan tidak menimbulkan efek sama sekali?

e. Apakah jika dikemudian hari timbul efek, betulkah efek itu disebabkan oleh hukum?

f. Apakah sebenarnya kegunaan hukum kontrak itu?

g. Betulkah orang membuat kontrak untuk nanti dilaksanakan? Siapa menggunakannya? Kapan? Secara bagaimana?

h. Mengapa hukumnya menjadi seperti itu? Apakah memang harus begitu? Apakah tidak ada cara pengaturan alternatif?

Mengenai diskrepansi antara hukum dalam undang-undang dan dalam kenyataannya, sebuah ujaran sosiologis mengatakan "The Myth Of the operation of the law is given the lie daily". (Raharjo, 2010 : 62) Gambar yang penuh atau realitas sosial hukum memang memunculkan berbagai variable sosiologis, seperti asal-usul atau latar belakang sosial, pendidikan, kepercayaan, umur, golongan etnis, ras dan kedudukan ekonomi. Penelitian sosiologis dan stastistik di amerika membuktikan hal-hal tersebut. Ancaman hukuman mati, misalnya lebih sering 
digunakan apabila yang dihadapi adalah sengketa antara sesame kulit putih dibanding kulit hitam. Pengamatan selama lima tahun (pada tahun 70-an) menemukan bahwa perbandingan tersebut adalah rata-rata lima kali. Pengamatan selama lima tahun (pada tahun 70-an) menemukan bahwa perbandingan tersebut adalah rata-rata lima kali di negara bagian Florida, Georgia, Texas, dan Ohio. Sedangkan apabila orang kulit hitam didakwa membunuh kulit putih, maka frekuensi dijatuhkannya hukuman mati adalah lebih tinggi disbanding apabila kulit putih membunuh sesamanya, yaitu: di Ohio (hampir 15 kali), Georgia (lebih daripada 30 kali), florida (hampir 40 kali), dan texas (hampir 90 kali) lebih tinggi.

Untuk menjelaskan optik deskriptif sosiologis yang digunakan teori hukum progresif dan perbedaanya dengan optic preskriptif dalam ilmu hukum analitis-positivis, Donald black membuat dua modal hukum yang sangat membantu melihat perbedaan tersebut. Dari dua model tersebut dapat diketahui apa yang menjadi focus, proses dan sebagainya, apabila kita memasuki hukum progresif. Dapat diketahui bahwa apa yang menjadi perhatian hukum progresif bukanlah peraturan yang mengandung muatan abstrak dan stereotipis, melainkan apa yang teramati dalam kenyataan. Dengan demikian, hukum adalah hukum bukan karena peraturannya mengatakan demikian, melainkan karena teramati dalam kenyataan. Dalam istilah Black, maka yang teramati dalam kenyataan adalah struktur sosial. Pada watu Steward Macaulay melakukan penelitian sosilogis terhadap kontrak dalam dunia bisnis di Amerika, maka struktur sosial tersebut adalah hal-hal yang senyatanya dilakukan oleh para pengusaha Amerika apabila memasuki hubungan kontrak.

\begin{tabular}{|c|c|c|}
\hline & $\begin{array}{c}\text { Model } \\
\text { Analitis Positivistis } \\
\text { (Jurisprudential) }\end{array}$ & $\begin{array}{c}\text { Model Sosiologis } \\
\text { (Sociological) }\end{array}$ \\
\hline Fokus Proses & Peraturan Logika & Struktur Sosial Perilaku (Behavior) \\
\hline Lingkup Perspektif & Universal Pelaku (Participant) & Variabel Pengamat (Observer) \\
\hline Tujuan Sasaran & Praktis Keputusan (Decision) & Ilmiah Penjelasan \\
\hline
\end{tabular}

Dalam hukum progresif, disebabkan oleh perhatian terhadap struktur sosial tersebut, maka hukum juga tidak memiliki lingkup universal, melainkan variable. Pada waktu melakukan kajian hukum 
progresif, maka variabel-variabel sosiologis dimasukkan, seperti latar belakang sosial dan ekonomi, kedudukan dalam masyarakat, juta etnis dan ras. Sebagaimana diperlihatkan oleh penelitian sosiologis di amerika, maka variabel ras kulit hitam atau putih memiliki pengaruh yang jelas dalam penegakan hukum. Demikian pula dengan kritik Gerry Spence terhadap ujaran "Equal Justice Under Law" yang terpampang pada dinding Supreme Court, yang hanya benar apabila ditambahkan kata-kata sehingga menjadi "Equal Justice Under Law, to All who can Afford it".

Pemisahan tajam antara optik preskriptif dan deskriptif dalam pendidikan hukum yang hanya akan menghasilkan gambar yang tidak utuh mengenai hukum. Kebutuhan dan tuntutan profesi rupa-rupanya sangat menentukan agar pendidikan hukum ditekankan pada model analitis-positivistis itu. Menurut Achmad Ali (1998: 14), Metode Sosiologi Hukum yang melahirkan hukum progresif dalam meningkatkan daya hukum positif menyelesaikan permasalahanpermasalahanya nyata ialah:

a. hukum mampu menjawab mengapa manusia patuh pada hukum dan mengapa dia gagal untuk menaati hukum tersebut serta faktor-faktor sosial lain yang memengaruhinya

b. hukum memberikan kemampuan-kemampuan bagi pemahaman terhadap hukum di dalam konteks sosial.

c. hukum memberikan kemampuan-kemampuan untuk mengadakan analisis terhadap efektivitas hukum dalam masyarakat, baik sebagai sarana pengendalian sosial, sarana untuk mengubah masyarakat,maupun sarana untuk mengatur interaksi sosial, agar mencapai keadaan-keadaan sosialtertentu.

d. hukum memberikan kemungkinan dan kemampuan-kemampuan untuk mengadakan evaluasi terhadap efektivitas hukum di dalam masyarakat.

Menurut Muhammad Abduh Sosiologi hukum yang melahirkan hukum progresif memiliki kegunaan antara lain, memberikan kemampuan bagi pemahaman terhadap hukum dalam konteks sosial; penguasaan konsep-konsep sosial hukum dapat memberikan 
kemampuan untuk mengadakan analisa terhadap efektifitas hukum dalam masyarakat baik sebagai sarana pengendalian sosial, sarana untuk mengubah masyarakat, sarana mengatur interaksi sosial agar mencapai keadaan-keadaan sosial tertentu; sosiologi hukum memberikan kemungkinan serta kemampuan untuk mengadakan evaluasi-evaluasi terhadap efektifitas hukum dalam masyarakat (Abduh, 2002: 4). Menurut Khudzaifah Dimyati Sosilogi hukum yang melahirkan hukum progresif berguna untuk memberikan kemampuan bagi pemahaman terhadap hukum di dalam sosial. Penguasaan konsep-konsep sosiologi hukum dapat memberikan kemampuan untuk mengadakan analisis terhadap efektivitas hukum dalam masyarakat, baik sebagai sarana untuk merubah masyarakat agar mencapai keadaan-keadaan sosial tertentu. Sosiologi hukum memberikan kemungkinan-kemungkinan untuk mengadakan evaluasi terhadap efektivitas hukum di dalam masyarakat (Dimyati, 2007).

Sosiologi hukum melahirkan hukum progresif adalah suatu cabang ilmu pengetahuan yang secara empiris dan analitis mempelajari hubungan timbal-balik antara hukum sebagai gejala sosial, dengan gejala-gejala sosial lain. Tujuan hukum progresif di dalam kenyataan seperti berikut: berguna untuk terhadap kemampuan memahami hukum di dalam konteks sosial, memberikan kemampuan untuk mengadakan analisis terhadap efektivitas hukum dalam masyarakat, baik sebagai sarana pengendalian sosial, mengubah masyarakat, mengatur interaksi sosial agar mencapai keadaan social yang tertentu dan memberikan kemungkinan-kemungkinan dan kemampuan untuk mengadakan evaluasi terhadap efektivitas hukum di dalam masyarakat. Hukum di Indonesia terbukti telah menjadi alat kekuasaan, hukum bukanlah sesuatu yang otonom karena menjadi sub sistem dari sistem lain yang lebih besar. Keadaan ini harus diperbaiki pada saat ini adalah momentum yang tepat untuk itu dimana hukum harus menunjukkan otoritasnya dan secara fleksibel mengikuti perkembangan dan tuntutan rakyat.

Pengertian yang fleksibel dari hukum di sini jangan diartikan bahwa hukum itu plin-plan dalam menghadapi perkembangan jaman, tetapi pengertian yang benar dalam konteks ini adalah bagaimana 
hukum dapat menempatkan diri dalam posisinya sebagai institusi yang keberadaannya dibutuhkan oleh rakyat dalam sebuah negara yang demokratif. Jadi lebih tepatnya fleksibelitas hukum ini dapat dikaitkan dengan adaptasi hukumterhadaptuntutanrakyat. Setiap peraturan hukum memberitahu tentang bagaiman seorang pemegang peranan (role occupant) itu diharapkan bertindak. Bagaimana seorang itu akan bertindak sebagai respons terhadap peraturan hukum merupakan fungsi-peraturan-peraturan yang ditujukan kepadanya, sanksisanksinya, aktivitas dari lembaga- lembaga pelaksana serta keseluruhan kompleks sosial, politik dan lain-lainnya mengenai dirinya.

Bagaimana lembaga-lembaga pelaksana itu akan bertindak sebagai respons terhadap peraturan hukum merupakan fungsi peraturan-peraturan hukum yang ditujukan kepada mereka, sanksi-sanksinya, keseluruhan kompleks kekuatan sosial, politik dan lain-lainnya yang mengenai diri mereka serta umpan balik yang datang dari pemegang peranan Bagaimana para pembuat undang-undang itu akan bertindak merupakan fungsi peraturan-peraturan yang mengatur tingkah laku mereka, sanksi sanksinya, keseluruhan kompleks kekuatan sosial, politik, ideologis dan lain-lainnya yang mengenai diri mereka serta umpan balik yang datang dari pemegang peran serta birokrasi (Faizal, 200).

Menurut Ahmad Biroli Kita tidak dapat menjelaskan tentang efektifitas hukum tanpa membicarakan lebih dahulu tentang hukum dalam tataran normative (law in books) dan hukum dalam tataran realita (law in action), sebab tanpa membandingkan kedua variable ini adalah tidak mungkin untuk mengukur tingkat efektifitas hukum. Donald Black berpendapat bahwa efektifitas hukum adalah masalah pokok dalam sosiologi hukum yang diperoleh dengan cara memperbandingkan antara realitas hukum dalam teori, dengan realitas hukum dalam praktek sehingga nampak adanya kesenjangan antara keduanya. Hukum dianggap tidak efektif jika terdapat perbedaan antara keduanya.

Untuk mencari solusinya, langkah solusinya, langkah apa yang harus dilakukan untuk mendekatkan kenyataan hukum (das sein) 
dengan ideal hukum (das sollen) agar 2 (dua) variabel (law in books dan law in action menjadi sama?). Hukum yang efektif adalah hukum yang sesuai dengan peraturan yang telah dibuat dalam undang-undang dan hukum yang sesuai dengan harapan atau cita-cita dari masyarakat. Manakala dengan adanya hukum tersebut akan menjadikan keteraturan sosial dalam masyarakat. Berbicara tentang hukum memang sangat pelik terdapat takaran sebuah kenyataan hukum dan sebuah ideal hukum. Kadangkala apa yang sudah menjadi ketetapan dalam undang-undang sebuah hukum tidak sesuai dengan keinginan masyarakat, ataupun sebaliknya masyarakat menginginkan sebuah hukum yang baru.

Berdasarkan penjalasan diatas dapat simpulkan bagaimana teori hukum progresif dengan metode dan konsepnya untuk meningkatkan daya mampu hukum positif menyelesaikan persoalan-persoalan nyata. Dengan mengunakan pendakatan hukum progresif, hukum mampu menjawab mengapa manusia patuh pada hukum dan mengapa dia gagal untuk menaati hukum tersebut serta faktor-faktor sosial lain yang memengaruhinya serta memberikan kemampuan-kemampuan bagi pemahaman terhadap hukum di dalam konteks sosial karena hukum progresif melihat hukum bukan dari ketentuan teks tetapi melihat konteks hukumnya oleh karena itu hukum progresif mampu memberikan kemampuan-kemampuan untuk mengadakan analisis terhadap efektivitas hukum dalam masyarakat, baik sebagai sarana pengendalian sosial, sarana untuk mengubah masyarakat, maupun sarana untuk mengatur interaksi sosial, agar mencapai keadaan-keadaan sosial tertentu.

2. Metode dan Konsepsi Penegakan Hukum dalam Perspektif Teori Sosiologi Hukum yang Mampu Mengatasi Kesejangan Hukum (Legal Gap) yang Ada di Masyarakat Indonesia

Untuk mengatasi jurang hukum tersebut satjipto raharjo membuka cakrawala hukum dengan gagasan hukumnya yaitu hukum progresif, pandangan ini tidak ditujukan untuk mengajak orang berpikir melawan sistem hukum. Hukum tetap memiliki sistemnya sendiri, tetapi sistem tersebut tidak bekerja sebagaimana dibayangkan oleh kaum egarasm 
hukum. Dalam tulisan ini, ingin diingatkan kembali sepuluh butir rangkaian kata-kata kunci yang menjadi benang merah dari pemikiran hukum progresif yang digagas oleh Satjipto Raharjo (2011: 55-58). Rangkaian kata-kata kunci tersebut adalah:

a. Hukum progresif itu untuk manusia, bukan manusia untuk hukum. Pada hakikatnya setiap manusia itu baik, sehingga sifat ini layak menjadi modal dalam membangun kehidupan berhukumnya. Hukum nukan menjadi raja (segalanya), tetapi sekedar alat bagi manusia untuk memberi rahmat ke pada dunia dan kemanusiaan. Hukum tidak ada untuk dirinya sendiri melainan untuk sesuatu yang lebih luas dan lebih besar, maka setiap diperbaiki, bukan manusia yang dipaksa-paksa untuk dimasukkan ke dalam skema hukum. Disini system hukum perlu ditempatkan dalam alur deep-ecology. Kata-kata kunci pada butir ini seyogyianya juga boleh dieja sebagai hukum untuk konteks kehidupan sejagat, di mana manusia bukan lagi titik sentral satu-satunya.

b. Hukum progresif itu harus pro-rakyat dan pro-keadilan. Harus berpihak kepada rakyat. Keadilan harus didudukan di atas peraturan. Para penegak hukum harus berani menerobos kekakuan teks (diistilahkan sebagai "mobilisasi hukum") jika memang teks itu mencederai rasa keadilan rakyat. Prinsip pro-rakyat dan pro-keadilan ini merupakan ukuran-ukuran untuk menghindari agar progresivisme ini tidak mengalami kemerosotan, penyelewengan, penyalahgunaan dan hal negative lainya.

c. Hukum progresif bertujuan mengantarkan manusia kepada kesejahteraan dan kebahagian. Hukum harus memiliki tujuan lebih jauh daripada yang diajukan oleh falsafah liberal. Pada falsafah pascaliberal, hukum harus mensejahterakan dan membahagiakan. Hal ini juga sejalan dengan cara pandang orang timur yang memerikan pengutamaan pada kebahagian.

d. Hukum progresif selalu dalam proses menjadi (law as a process, law in the making). Hukum bukan institusi yang final, melainkan ditentukan oleh kemampuannya mengabdi kepada manusia. Ia terus menerus membangun dan mengubah dirinya menuju kepada 
tingkat kesempurnaan yang lebih baik. Setiap tahap dalam perjalanan hukum adalah putusan-putusan yang dibuat guna mencapai ideal hukum, baik yang dilakukan legislative, yudikatif, maupun eksekutif. Setiap putusan bersifat terminal menuju kepada putusan berikutnya yang lebih baik. Hukum tidak pernah bisa meminggirkan sama sekali kekuatan-kekuatan otonom masyarakat untuk mengatur ketertibannya sendiri. Kekuatan tersebut akan selalu ada, sekalipun dalam bentuk terpendam (laten). Pada saat-saat tertentu ia akan muncul dan mengambil alih pekerjaan yang tidak bisa diselesaikan dengan baik oleh hukum Negara sebaiknya memang hukum itu dibiarkan mengalir saja.

e. Hukum Progresif menekankan hidup baik sebagai dasar hukum yang baik. Dasar hukum terletak pada perilaku bangsanya sendiri karena perilaku bangsa itulah yang menetukan kualitas berhukum bangsa tersebut. Fundamen Hukum tidak terletak pada Bahan Hukum (Legal Stuff), Sistem Hukum, berpikir hukum, dan sebagainya, melainkan lebih pada manusia atau perilaku manusia. Di tangan perilaku buru, system hukum akan menjadi rusak, tetapi tidak di tangan orang-orang dengan perilaku baik.

f. Hukum progresif memiliki tipe responsif. Dalam tipe responsive, hukum akan selalu dikaitkan pada tujuan-tujuan di luar narasi tekstual hukum itu sendiri, yang disebut oleh Nonet dan Selznick sebagai "The Souverignity of Purpose". Pendapat ini sekaligus mengritik doktrin due process of law. Tipe responsive menolak otonomi hukum yang bersifat final dan tidak dapat digugat.

g. Hukum progresif mendorong peran negara. Mengingat hukum memiliki kemampuan yang terbatas, maka mempercayakan segala sesuatu kepada kekuatan hukum adalah sikap yang tidak realistis dan keliru. Disisi lain, masyarakat ternyata memiliki kekuatan otonom untuk melindungi dan menata dirinya sendiri. Kekuatan ini untuk sementara tenggelam di bawah dominasi hukum modern yang notabene adalah hukum Negara. Untuk itu, hukum progresif sepakat memobilisasi kekutan otonom masyarakat (mendorong publik) 
h. Hukum progresif membangun Negara hukum yang berhatinurani. Dalam bernegara hukum, yang utama adalah kultur, "the cultural primacy". Kultur yang dimaksud adalah kultur pembahagian rakyat keadaan tersebut dapat dicapai apabila kita tidak berkutat pada "the legal structure of the state" melainkan haus lebih mengutamakan "a state with conscience". Dalam bentuk pertanyaan, hal tersebut akan berbunyi; "bernegara hukum untuk apa?" dan dijawab dengan: "bernegara untuk membahagikan rakyat".

i. Hukum progresif dijalankan dengan kecerdasan spiritual. Kecerdasan spiritual tidak ingin dibatasi patokan (rule-bound), juga tidak hanya bersifat kontekstual, tetapi ingin keluar dari situasi yang ada dalam usaha mencari kebenaran makna atau nilai yang lebih dalam.

j. Hukum progresif itu merobohkan, mengganti, dan membebaskan. Hukum progresif menolak sikap status quo dan submisif. Sikap status quo menyebabkan kita tidak berani melakukan perubahan dan menganggap doktrin sebagai sesuatu yang mutlak untuk dilaksanakan. Sikap demikian hanya merujuk kepada maksim "rakyat untuk hukum"

Berdasarkan pandangan tersebut diatas ilmu sosiologi hukum dapat melahirkan teori hukum progresif yang dapat mengawinkan kepastian hukum, keadilan dan kemanfaatan dari 10 kata kunci tersebut diharapkan dapat mengatasi jurang hukum (legal gap) yang terjadi dimasyakarat Indonesia (Sidharta, 2013: 2018).

\section{Peran sosiologi hukum dan teori hukum progresif terhadap penegak hukum Indonesia}

Di Indonesia dikenal beberapa penegak hukum atau pelaksana hukum seperti; hakim, jaksa polisi, advokat yang masing-masing mempunayi fungsi-fungsi sendiri-sendiri. Yang menjadi persoalan bagaimana peranan sosiologi hukum terhadap para Penegak Hukum atau pelaksana hukum yang ada dalam 151egara kita, karena tidak dapat dipungkiri penegak hukum adalah (gap filler) pengisi jurang hukum tersebut. 
a. Polisi

Polisi sangat berperan penting dalam penegakan hukum dalam menindak suatu persoalan hukum, menggunakan perspektif sosiologi hukum dengan teori hukum responsive, polisi diharapkan dapat melihat hukum bukan dari segi tekstual tetapi kontekstual di lapangan masyarakat, dalam penegakan hukum pidana garda awal ada polisi (Harahap, 2012: 91). Perlu dilihat bahwasanya proses hukum acara pidana baru akan terjadi jika ada laporan (pasal 1 angka 24 Kuhap), pengaduan (Pasal 1 angka 25 Kuhap) dan Tangkap tangan atau pengetahuan penyidik itu sendiri (Pasal 1 angka 19), jika kita melihat dari koridor hukum tersebut sebelum masuk dalam proses hukum acara pidana, polisi diharapkan melakukan pendekatan hukum progresif, polisi harus mengetahui apakah ini adalah peristiwa itu memang merupakan peristiwa pelanggaran hukum atau bukan, hal ini sangat berpengaruh pada mengatasi legal gap karena dipaksanakanya transplantasi hukum ke daerah tertentu.

b. Jaksa

Jaksa sebagai penegak hukum menerima berkas perkara penyidikan dari kepolisian dapat berperan sebagai (Gap Filler) dengan meneliti berkas penyidikan apakah yang disidik oleh polisi benar-benar peristiwa pidana atau bukan ?, jika bukan peristiwa pidana, jaksa berhak mengembalikan berkas perkara penyidikan kembali pada penyidik (P-19) karena jaksa akan terbentur pada pembuatan surat dakwaan yang dalam hukum acara pidana harus merujuk pada ketentuan peraturan perundang-undangan yang dilanggar (Harahap, 2012). Dengan pendekatan hukum progresif jaksa dapat berperan mengatasi legal gap dengan cara sebagai berikut:

1) pada tahap sebelum pembuatan surat dakwaan dengan pengembalian berkas kepada penyidik dengan pemberian pentunjuk (Pasal 110 ayat (2) Kuhap)

2) Tahap Persidangan dengan melihat fakta hukum dipersidangan apakah ada legal gap yang terjadi diperistiwa hukum tersebut.

3) Tahap Penuntutan dengan memberikan hal yang meringankan 
terdakwa dengan menggunakan pendekatan sosiologi hukum, membuka tabir apakah memang terjadi legal gap dan jaksa berperan sebagai (Gap filler)

c. Advokat

Advokat sebagai penegak hukum juga menempati posisi yang sama (gap filler), dalam pendekatan sosiologis hukum advokat dianggap sebagai pembela masyarakat atau profesi yang mulia (Officium Nobile), dalam koridor hukum acara pidana advokat dapat menjadi penjebatan kesalahan penerapan hukum pada masyarakat (legal gap) dari pemeriksaan pendahuluan sampai dengan pemeriksaan pengadilan, dalam pemeriksaan pendahuluan advokat dapat berperan sebagai (gap filler) pengisi jurang antara penegak hukum yang melihat dari sisi normative saja dengan pendekatan sosiologis hukum yang terjadi dimasyakarat tertentu oleh karena itu advokat dianggap sebagai penjembatan hal tersebut, dalam pemeriksaan pengadilan advokat dapat menyajikan fakta hukum secara sosiologis dalam nota keberatannya (Eksepsi) dan dalam nota pembelaannya (Pledoi) sehingga kepastian hukum, keadilan, dan kemanfaatan dapat terjadi di muka pengadilan.

d. Hakim

Menurut Sidharta Persoalan jurang hukum (Legal Gaps) adalah siapa yang harus diberi pedan menjadi pengisi jurang (Gap Filler) ini. Oleh karena jurang ini paling kerap terjadi pada peristiwa-peristiwa konkret yang memiliki akibat hukum, maka figure profesi hukum yang paling otoratif menuntaskannya adalah hakim, bahkan ketiga hakim dianggap sebagai status quo sekalipun. Dengan mengutip sosiologi hans Morgenthau, Steven Vago pernah menyatakan, "A gives status quo is stabilized and perpuated in a legal system and that the courts, being the chief instruments of a legal system, must act as agents of the status quo.

Jika Polisi ada garda awal penerapan hukum progresif dalam penegakan hukum, maka hakim adalah pintu terakhirnya, semua muara peristiwa hukum pidana berakhir pada putusan hakim, oleh karena itu sidharta menyebut hakim sebagai pengisi jurang hukum 
tersebut, hakim diharapkan mampu menggali tidak hanya hukum positif secara normatif akan tetapi juga hukum secara empiris yang berlaku dimasyakat, hakim sebagai garda akhir harus melihat dalam masyarakat yang masih mengenal hukum tidak tertulis, serta berada dalam masa pergolakan dan peralihan, Hakim merupakan perumus dan penggali dari nilai-nilai hukum yang hidup di kalangan rakyat. Untuk itu ia harus terjun ke tengah-tengah masyarakat untuk mengenal, merasakan dan mampu menyelami perasaan hukum dan rasa keadilan yang hidup dalam masyarakat. Dengan demikian Hakim dapat memberikan putusan yang sesuai dengan hukum dan rasa keadilan masyarakat".

Fenomena ini sudah beberapakali terjadi seperti hakim bismar Siregar, Adi Andoyo Soetjipto dan masih banyak lagi. Kedua contoh hakim tersebut sekedar contoh karena sering keputusannya dianggap kontroversional akan tetapi mampu menyelaraskan kepastian hukum, keadilan dan kemanfaatan bagi masyarakat tersebut, selain itu didalam tulisan Mafud M.D yang berjudul "Inilah Hukum Progresif Indonesia" beliau menceritakan pengalaman menerapkan hukum progresif saat memimpin mahkamah konstitusi, dimana pada saat MK memutus kasus Pilkada Jawa Timur tanggal 14 November 2008, ketika itu, pada 14 november 2008, sebuah gugatan didaftarkan oleh kuasa hukum pasangan Calon Gubernur Jawa timur, Khofifah indar Parawansa-Mudjiono (kaji).

Tim Kaji mempermasalahkan hasil perhitungan suara pemilihan kepada daerah (pilkada) jawa timur di empat kabupaten di Madura dan sejumlah kabupaten lainnya. Pasangan ini kalah tipis 60.223 suara dari pasangan calon gubernur terpilih, soekarwo dan saifullah yusuf (karsa). Karsa meraup suara 7.792.994, sedangkan pasangan kaji hanya memperoleh 7.669.721. tim kaji menduga terjadi kecurangan dalam perhitungan di sejumlah daerah tersebut.

Berdasarkan ketentuan undang-undang, kewenangan MK dalam mengadili perkara sengketa pemilukada tak lebih dari pengadilan angka. MK tidak boleh memerintahkan diselenggarakannya pemilu ulang atau memerintahkan pemungutan 
suara ulang. Sebab, pemilu ulang itu hanya boleh dilakukan oleh dan atas perintah KPU apabila terjadi bencana atau huru-hara social atau keadaan tertentu lainya. Tetapi MK kemudian membuat terobosan dengan melanggar ketentuan undang-undang dengan alasan ketentuan tersebut tidak memberi jaminan keadilan karena dalam praktiknya sering diakali dengan berbagai cara.

Terobosan yang dilakukan MK tersebut bertujuan untuk membangun keadilan substantive. Artinya, apa yang dibangun di MK bukan kebenaran tertulis semata, melainkan keadilan. Itulah sebabnya, dalam kasus perselisihan hasil pemilu kepala daerah jawa timur, untuk pertama kalinya MK membuat putusan yang menyatakan bahwa pemilu di sejumlah tempat dijawa timur dan Madura harus diulang. Ada yang diperintahkan pemungutan suara ulang, ada juga yang diperintahkan perhitungan ulang. Pada saat itu MK melahirkan semacam teori tentang pelanggaran yang bersifat TSM yakni terstruktur sistematis, dan massif. Sebuah hasil pemilu yang oleh KPU dinyatakan sah kemudian digugat (diperkarakan) ke MK karena terjadinya pelanggaran yang bukan hanya terkait dengan kesalahan penghitungan suara maka jika pemohon bisa membuktikan terjadi pelanggaran yang bersifat TSM melalui proses pemeriksaan di persidangan yang terbuka MK bisa membatalkan putusan KPU tersebut. Pelanggaran yang bersifat terstruktur artinya pelanggaran itu dilakukan dengan menggunakan struktur pemerintahan atau lembaga KPU/KPUD sendiri merekayasi hasil atau kecurangan-kecurangan agar ada pihak yang menang atau kalah diluar kehendak rakyat dan kehendak hukum yang mengghendaki pemilu diselenggarakan luber dan jurdil. Sistematis artinya hasil pemilu direncanakan sedemikian rupa sebelum pemungutan suara melalui langkah-langkah nyata yang terencana untuk mengalahkan memenangkan kontestan pemilu atau pemilukada. Massif artinya mengakibatkan kesalahan hasil secara besar-besaranan karena mengehegemoni komunitas yang besar. Itulah yang kemudian bisa dibuktikan di sebagian daerah jawa timur meskipun setelah diulang masih belum mengubah hasil yang signifikan (Mahfud: 3). Dari penjelasan diatas dapat disimpulkan 
Sosiologi Hukum dengan teori hukum progresif terbukti mampu mengatasi kesenjangan hukum (legal gap) yang terjadi pada hukum Indonesia, dengan menciptakan Gap Filler sebagai pengisi jurang hukum tersebut.

\section{SIMPULAN}

Metode Kerja Teori Hukum Progresif dapat dipertukarkan dengan metode ilmiah, oleh karena memenuhi standar-kerja metode keilmuan pada umumnya, yaitu (1) membuat deskripsi mengenai objek,(2) membuat penjelasan (explanation), (3) mengungkapkan (reveling), dan (4) membuat prediksi. Teori Hukum Progresif berbagi sama degan ilmu pengetahuan dalam mencari kebenaran berdasarkan kenyataan. Hal ini sangat berbeda dengan ilmu hukum normative-positivis yang bertolak dari hukum perundang-undangan. Karena pencarian pengungkapan dan penjelasan mengenai hal yang sebenarnya itu maka sosiologi hukum berseberangan dengan ilmu hukum normative tersebut yang melakukan pemihakan dan penilaian terhadap hukum. Dilihat dari segi sudut kriteria pekerjaan ilmu pengetahuan modern diatas, maka ilmu hukum yang diajarkan difakultas-fakultas hukum baru dapat disebut sebagai Pratical Science.

Usaha untuk mencari kebenaran-kenyataan tersebut menjadikan pengamatan (observation) sangat sentral dan yang menjadikan Teori Hukum Progresif sebagai ilmu pengetahuan empiric, dengan pendekatan tersebut Hukum Progresif mampu memberikan sumbangsih yang nyata dalam meningkatkan daya kerja hukum positif karena Teori Hukum Progresif tidak melihat hukum hanya dari sudut pandang perundang-undangan akan tetapi melihat hukum dari sisi kebenaran-kenyataan yang ada dimasyarakat tersebut. Teori hukum dengan pendekatan hukum progresif memberi kritik terhadap kebekuan produk legislasi, yang membun para fungsionaris (pengemban) hukum terjebak dalam cara pandanga monolitik dalam menyisiati jurang ukum yang terbentuk akibat kelemahan produk legislasi tersebut. Progetivitas dalam berhukum menuntut ada keberanian untuk melakukan terobosan guna mencairkan kebekuan tadi, sekaligus membangun jembatan diatas jurang hukum tadi melalui penemuanpenemuan hukum agar dapat meseleraskan kepastian hukum, keadilan dan kemanfaatan bagi masyarakat Indonesia. 


\section{DAFTAR REFERENSI}

Ali, Achmad. Menjelajahi Kajian Empiris Terhadap Hukum. Jakarta: Yasif Watampone. 1998.

Abduh, Muhammad, Sosiologi Hukum. Medan: Modul Kuliah Sekolah Pascasarjana Universitas Sumatera Utara, 2002

Dimyati, Khudzaifah. Pola Pemikiran Hukum Responsif: Sebuah Studi atas Proses Pembangunan Hukum Indonesia. Jurnal Ilmu Hukum. 2007.

N.D, Mukti. Fajar., \& Achmad, Yulianto. Dualisme Penelitian Hukum Normatif \& Empiris, Yogyakarta: Pustaka Pelajar, 2010.

Harahap, Yahya. Pembahasan Permasalahan dan Penerapan Kuhap Penyidikan dan Penuntutan. Jakarta: Sinar Grafika. 2012.

Marzuki, Peter. Mahmud. Penelitian Hukum Normatif, Jakarta: Kencana, 2005.

Marzuki, Peter. Mahmud. Pengantar Ilmu Hukum. Jakarta: Kencana Prenada Media Group. 2008.

Weber, Max, On Law in Economy and Society, Max Rheinstein (ed.), Edward Shils \& Max Rheinstein (Transl.)., New York: Clarion Book, 1954

Chambliss, William J., \& Robert B. Seidmen, Law, Order, And Power, Reading, Mass: Addison-Wesley, 1971.

Mastur. (n.d.). Peranan dan Manfaat Sosiologi Hukum Bagi Aparat Penegak Hukum. Jurnal Ilmiah Hukum Qisti.

MD, Moh. Mafud. Dekontruksi dan Gerakan Pemikiran Hukum Progresif. Semarang: Thafa Media. 2013.

Raharjo, Satjipto. Menggagas Hukum Progresif Indonesia. Semarang: Pustaka Pelajar atas Kerjasama IAIN Walisongo dan Program Doktor Ilmu Hukum Universitas di Ponegoro. 2006.

Raharjo, Satjipto. Sosiologi Hukum Perkembangan Metode dan Pilihan Masalah. Yogyakarta: Genta Publishing. 2010.

Sidharta. Pendekatan Hukum Progresif dalam Mencairkan Kebekuan Produk Legislasi dalam buku Dekontruksi dan Gerakan Pemikiran Hukum Progresif. Semarang: Thafa Media \& Konsorsium Hukum Progresif Universitas Diponegoro Semarang . 2013.

Sidharta. Moralitas Profesi Hukum: Suatu Tawaran Berpikir. Bandung: Refika Aditama. 2009.

Wignjosoebroto, Soetandyo. Hukum, Konsep dan Metode. Malang: Setara 
Press, 2013.

Aziz, Noor. Muhammad. Urgensi Penelitian Dan Pengkajian Hukum dalam Pembentukan Perundang-Undangan. Recht Vinding, Vol 1 No.1.

Faizal, Liky. (2009). Sosiologi Hukum dan Paradigma Sosial. Jurnal Tapis, Jurnal Tapis Vol.5 No.10.

Galanter, Marc. "Why the 'Haves' Come Out Ahead: Speculation on the Limits of Legal Change", Law and Society, Fall, 1974

Kuliah Teori Hukum Magister Ilmu Hukum Fakultas Hukum Universitas Islam Indonesia Prof. Guntur Hamzah, S.H., M.H.

Bahan Kuliah Sosiologi Hukum "Problem Penegakan Hukum" oleh Dr. Suparman Marzuki, S.H., M.Si

M.Irsyad. S.H., M.H., Materi Kuliah Kemahiran Pendampingan pada Pemeriksaan Pendahuluan Pada Pendidikan Khusus Profesi Advokat, Fakultas Hukum Universitas Islam Indonesia dan PERADI

Andi Saputra, 10 Kasus Yang Mengguncangkan Hukum di Indonesia, detikNews,

Desember2011,http://news.detik.com/read/2011/11/25/052438/177525

3/10/10-kasus-yang-mengguncang-hukum-indonesia?n991102605 